\title{
TREATMENT OF THE EFFLUENT FROM A KRAFT BLEACH PLANT WITH WHITE ROT FUNGI Pleurotus sajor caju AND Pleurotus ostreatus
}

\author{
A. BELÉM ${ }^{1}$ \\ A.V. PANTELEITCHOUK ${ }^{1}$ \\ A.C. DUARTE ${ }^{2}$ \\ T.A.P. ROCHA-SANTOS ${ }^{1}$ \\ A.C. FREITAS ${ }^{1, *}$
}

Received: $18 / 12 / 07$

Accepted: 18/03/08

\author{
${ }^{1}$ ISEIT/Viseu - Instituto Piaget, Estrada do Alto do Gaio \\ Galifonge, 3515-776 Lordosa, Viseu, Portugal \\ ${ }^{2}$ CESAM \& Department of Chemistry, University of Aveiro \\ 3810-193 Aveiro, Portugal
}

\begin{abstract}
The final effluents from pulp and paper industry, even after biological treatment, often contain a plethora of unwanted by-products, which confer them colour and toxic characteristics. The aim of this work was to promote degradation of organic matter and remove colour by contacting fungi Pleurotus sajor caju or $P$. ostreatus with effluents from kraft pulp mill after treatment by an activated sludge process. Absorbance reduction of 57 and $76 \%$ was observed after 14 days of treatment of final effluent with glucose by $P$. sajor caju, at 400 and $460 \mathrm{~nm}$, respectively. Lower values of absorbance reduction were observed in final effluent with additives and inoculated with the same species (22 to 29\%). Treatment with $P$. ostreatus was more efficient in the effluent with additives, 38.9 to $43.9 \%$ of reduction. Higher growth rate of $P$. sajor caju was observed in the effluent with glucose. Biological treatment resulted in $65-67 \%$ reduction of COD after 14 days revealing no differences for each effluent composition and inoculated species. Profiles of composition of organic compounds obtained by GC-MS showed no significant differences between the two effluents treated with $P$. sajor caju or $P$. ostreatus, but longer incubation time reflected higher reduction of organic compounds.
\end{abstract}

KEYWORDS: Kraft effluent, Biological treatment, Fungi, Pleurotus

\section{INTRODUCTION}

The pulp and paper industry still is an important economic activity in several countries around the world (USA, Canada, India, Portugal, etc.) although being considered as one of largest polluters (Pokhrel and Viraraghavan, 2004). Each pulp mill utilizes large amounts of water, which reappear in the form of an effluent containing large amounts of organic compounds. The higher molecular weight compounds may be biologically inactive since they cannot penetrate inside the cellular membrane of living organisms, but the degradation of such compounds results in lower molecular weight compounds which could be active and toxic to living organisms. Some fungi are able to degrade the chlorolignins, resulting in effluent decolourisation since these compounds are the main responsible for the brown colour of final effluent. Fungi have been attracted great interest for biological treatment of wastewaters (Coulibaly et al., 2003), since for example wood rotting fungi are capable of degrading lignin, which is a polymeric structure with aromatic rings (Nilsson et al., 2005), and have proved their potential in the lignin/phenolic wastewater treatment since they produce enzymes including lignin peroxidases, MnP-dependent peroxidases and laccases (Conesa et al., 2002) which are capable of degrading lignin found in pulp bleaching effluents (Lankinen et al., 1990). Peroxidases are oxidoredutases that utilize peroxide to catalyze the oxidation of a variety of organic and inorganic compounds (Conesa et al., 2002). White-rot fungi have been used in studies concerning biological treatment of a pulp and paper industry effluent, namely Pleurotus species (Ragunathan and Swaminathan, 2004; Santos et al., 2002). 
The aim of this work was the biological treatment of Eucalyptus globulus kraft pulp mill effluent, derived from the secondary treatment, by Pleurotus sajor caju and $P$. ostreatus in order to achieve colour reduction and decrease of organic compounds content.

\section{MATERIAL AND METHODS}

\subsection{Source of inoculum and maintenance}

Two species of Pleurotus: $P$. sajor caju and $P$. ostreatus were obtained from Faculdade de Ciências Agrárias - UNESP, São Paulo Brasil, subcultured and maintained on Potato Dextrose Agar (Himédia $\AA$, Índia) at $4^{\circ} \mathrm{C}$. Growth of Pleurotus mycelia was performed in sterilized media containing $2 \mathrm{~g} \mathrm{I}^{-1}$ glucose (Riedel-Haen ${ }^{\circledR}$, Germany), $2 \mathrm{~g} \mathrm{I}^{-1}$ starch (Absolve ${ }^{\circledR}$, Portugal), $0.1 \mathrm{~g} \mathrm{I}^{-1}$ peptone (Himédia ${ }^{\circledR}$, India) and fragments of wheat straw (1\%) during 7 days at $25^{\circ} \mathrm{C}$ and $120 \pm 10 \mathrm{rpm}$. After growth, mycelia was collected by filtration with sterilized gaze and kept in sterilized plastic containers at $4^{\circ} \mathrm{C}$, for a maximum of $24 \mathrm{~h}$, until the biological treatment of the final effluent from the kraft pulp mill (final effluent).

\subsection{Effluent source}

A final effluent, from a bleached kraft pulp mill processing Eucalyptus globulus after secondary treatment by an activated sludge process, was collected in glass bottles, acidified at $\mathrm{pH} 2$ and kept at room temperature before analysis.

\subsection{Treatment of the effluent in batch reactor}

The ligninolytic fungi Pleurotus sajor caju and Pleurotus ostreatus were used to treat final effluent in batch reactors with $180 \mathrm{ml}$. According to previous experiences results (Belém et al., 2006), it was performed two assays to treat this effluent. In first experience the final effluent medium composition was according to Nagarathnamma \& Bajpai (1992) and was denominated as final effluent with additives. In this assay $1 \mathrm{~g} \mathrm{l}^{-1}$ glucose, $1.5 \mathrm{~g} \mathrm{l}^{-1} \mathrm{CaCl}_{2}$ (Aldrich $\AA$, Steinheim), $2.0 \mathrm{~g} \mathrm{I}^{-1} \mathrm{MgSO}_{4}$ (Panreac $\AA$, Spain), $1.5 \mathrm{~g} \mathrm{l}^{-1} \mathrm{NaH}_{2} \mathrm{PO}_{4}$ (Riedel-Haen $\AA$, Germany) and $0.15 \mathrm{~g} \mathrm{I}^{-1} \mathrm{NH}_{4} \mathrm{Cl}$ (Sigma ${ }^{\circ}, \mathrm{USA}$ ) were added to the effluent which was inoculated with 5-6 g of mycelia of $P$. sajor caju or $P$. ostreatus, respectively. In the second assay, it was tested the addition of $2 \mathrm{~g} \mathrm{l}^{-1}$ of glucose only, to the effluent which was inoculated with $6 \mathrm{~g}$ of mycelia of P. sajor caju. In both assays, initial $\mathrm{pH}$ of effluent with additives or with glucose were adjusted to $5.4-5.6$ and incubated at $25^{\circ} \mathrm{C}$ and $120 \pm 10 \mathrm{rpm}$ through 14 days.

\subsection{Determination of absorbance reduction, $\mathrm{pH}$, biomass and COD}

Both assays were performed with two replicas where several parameters were analysed to monitories the biological treatment of final effluent with Pleurotus spp. Samples were withdrawn after $0,2,5,7,9$ and 14 days of incubation for $\mathrm{pH}$ and absorbance control. Absorbance removal was followed by UV-VIS scan $(200-600 \mathrm{~nm})$ of diluted samples at pH 5.5. Chemical oxygen demand (COD) was analyzed according to ASTM method (1994) after 0 and 14 days of incubation. Mycelia from the two species of Pleurotus was harvested by filtration and weighed after 7 and 14 days of treatment for biomass control.

\subsection{Organic compounds analysis}

Both the final effluent and the treated effluent samples, after 7 and 14 days of incubation, were characterized for organic compounds using solid phase extraction followed by analysis with Fourier transform infra-red spectroscopy (FTIR) and gas chromatography coupled to mass spectrometry (GC-MS).

After assembling the ENV1-Disk Holder with ENV1-18 Disks (C18 bonded phase), $5 \mathrm{ml}$ of Dichloromethane (Labscan ${ }^{\circledR}$, Ireland), $5 \mathrm{ml}$ of methanol (Labscan ${ }^{\circledR}$, Ireland) and $5 \mathrm{ml}$ of MilliQ Plus Water were added followed by $180 \mathrm{ml}$ of sample. The sample was then extracted with $2 \times 10 \mathrm{ml}$ of acetonitrile (Labscan, Ireland) and dried in a rotative evaporator.

The dry extract was then derivatized by adding $250 \mu \mathrm{l}$ of pyridin (Fluka ${ }^{\circ}$, Switzerland), $250 \mu \mathrm{l}$ of BSTFA (Acros ${ }^{\circledR}$, USA) and $50 \mu$ of TMSCl (Aldrich ${ }^{\circledR}$, Germany). A GC-MS Shimadzu QP1100Ex with a capillary column CPSil8CB low bleed MS $(30 \mathrm{~m} \times 0.25 \mathrm{~mm} \times 0.25 \mathrm{~mm}$ film $)$ was used for the analysis of organic compounds. The column initial temperature was $40^{\circ} \mathrm{C}$ during $4 \mathrm{~min}$; program rate was $10^{\circ} \mathrm{C} / \mathrm{min}$ until $270^{\circ} \mathrm{C}$ and maintained during $30 \mathrm{~min}$. Injector 
temperature was kept at $250^{\circ} \mathrm{C}$ during all the analysis and it was injected $0.5 \mu$ of sample after derivatisation.

Spectra of dry extracts were also collected in a FTIR (Brucker) in $4 \mathrm{~cm}^{-1}$ resolution.

\section{RESULTS}

The $\mathrm{pH}$ profile throughout time incubation was different in the two final effluents inoculated with Pleurotus spp.; higher values (4.9 to 7.6) were recorded in the effluent with glucose throughout the 14 days of incubation at $25^{\circ} \mathrm{C}$ and $120 \pm 10 \mathrm{rpm}$ (Figure 1). Much lower values were attained in effluent with additives and treated with $P$. sajor caju or $P$. ostreatus, which attained values of $\mathrm{pH} 3$ between 5 and 7 days of incubation. This pattern is probably related with different biological pathways performed by Pleurotus spp resulting in different metabolic compounds or degradation products. Fungi are recognized for their superior aptitudes to produce a large variety of extra cellular proteins, organic acids and other metabolites (Palma et al., 1999).

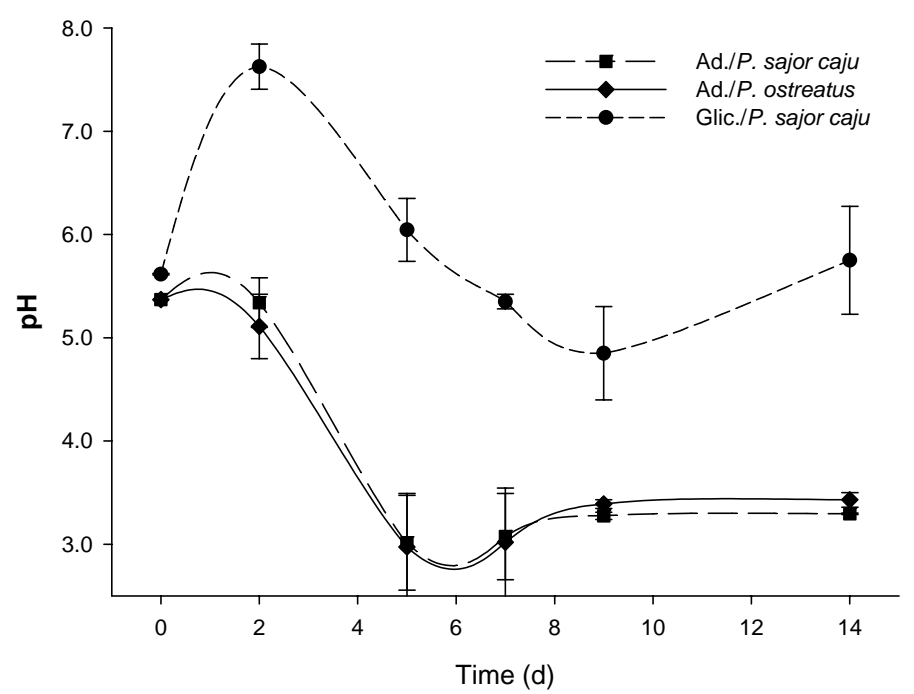

Figure 1. $\mathrm{pH}$ variation throughout time of final effluent with additives or glucose and inoculated with $P$. sajor caju or $P$. ostreatus at $25^{\circ} \mathrm{C}$ and $120 \pm 10 \mathrm{rpm}$

Growth rate of $P$. sajor caju was also improved in the effluent with glucose, 3.5 times against 1.3 in the final effluent with additives. In terms of COD values, biological treatment with fungi resulted in $65-67 \%$ reduction after 14 days of incubation in both experiences revealing no significant differences for each effluent composition and inoculated specie.

Table 1. Biomass and COD values obtained in treated final effluent with $P$. sajor caju or $P$. ostreatus, throughout 14 days of incubation at $25^{\circ} \mathrm{C}$ and $120 \pm 10 \mathrm{rpm}$

\begin{tabular}{lccccccc}
\hline Effluent & \multirow{2}{*}{ Fungi } & \multicolumn{4}{c}{ Biomass $\left(\mathrm{g} \mathrm{I}^{-1}\right)$} & \multicolumn{2}{c}{$\mathrm{COD}\left(\mathrm{g} \mathrm{I}^{-1}\right)$} \\
\cline { 3 - 8 } composition & & $0 \mathrm{~d}$ & $7 \mathrm{~d}$ & $14 \mathrm{~d}$ & $\mathrm{GR}^{1}$ & $0 \mathrm{~d}$ & $14 \mathrm{~d}$ \\
\hline Additives & $P$. sajor caju & 28.7 & 34.3 & 38.4 & 1.3 & 82.3 & 29.1 \\
& & & & & & \\
Additives & $P$. ostreatus & 34.0 & 33.4 & 42.6 & 1.3 & 92.4 & 31.0 \\
& & & & & & \\
Glucose & $P$. sajor caju & 32.5 & 46.2 & 113.9 & 3.5 & 62.1 & 20.8 \\
\hline${ }^{1}$ Growth rate $=$ total biomass $\left(\mathrm{g} \mathrm{I}^{-1}\right) /$ initial biomass $\left(\mathrm{g} \mathrm{I}^{-1}\right)$ & &
\end{tabular}

Pleurotus spp. fungi were able to promote degradation of organic matter present in the effluent resulting in progressive absorbance reduction throughout time of incubation where glucose addition revealed a positive factor; 57 and $76 \%$ of absorbance reduction were achieved after 14 days of incubation in final effluent with glucose, and treated with $P$. sajor caju at 400 and $460 \mathrm{~nm}$, respectively. Lower values were observed in final effluent with 
additives and treated with the same specie: 29 and 22\% of absorbance reduction, respectively. In a laboratory scale treatment of effluent from a kraft bleach plant with $P$. sajor caju, the colour reduction reported after 6 days of incubation was $67 \%$ in a rotating biological contactor at $39^{\circ} \mathrm{C}$ (Ragunathan and Swaminathan, 2004).

$P$. ostreatus showed higher efficiency in the treatment of final effluent with additives since 38.9 and $43.9 \%$ of absorbance reduction at 400 and $460 \mathrm{~nm}$ was obtained after 14 days of incubation. $19.4 \%$ was the maximum removal colour in effluent from a kraft bleach plant by $P$. ostreatoroseus SING (Santos et al., 2002).

Table 2. Absorbance reduction (\%) ${ }^{1}$ for several wave lengths in treated final effluent with $P$. sajor caju or $P$. ostreatus, throughout 14 days of incubation at $25^{\circ} \mathrm{C}$ and $120 \pm 10 \mathrm{rpm}$

\begin{tabular}{|c|c|c|c|c|c|c|c|}
\hline \multirow{2}{*}{$\begin{array}{c}\text { Effluent } \\
\text { composition }\end{array}$} & \multirow{2}{*}{ Fungi } & \multirow{2}{*}{$\lambda(\mathrm{nm})$} & \multicolumn{5}{|c|}{ Time (d) } \\
\hline & & & 2 & 5 & 7 & 9 & 14 \\
\hline \multirow{11}{*}{ Additives } & \multirow{5}{*}{ P. sajor caju } & 250 & 3.6 & 24.4 & 8.9 & 24.2 & 16.8 \\
\hline & & 275 & 6.5 & 27.3 & 12.1 & 25.4 & 19.1 \\
\hline & & 325 & 5.1 & 28.3 & 6.1 & 26.4 & 19.0 \\
\hline & & 400 & 14.1 & 37.7 & 12.3 & 34.8 & 29.4 \\
\hline & & 460 & 16.4 & 39.0 & 3.5 & 28.6 & 22.2 \\
\hline & \multirow{6}{*}{ P. ostreatus } & & & & & & \\
\hline & & 250 & 12.6 & 15.0 & 13.3 & 17.8 & 9.9 \\
\hline & & 275 & 15.1 & 13.3 & 17.4 & 21.5 & 15.4 \\
\hline & & 325 & 18.6 & 8.5 & 11.8 & 21.9 & 28.3 \\
\hline & & 400 & 33.8 & $-^{2}$ & 14.5 & 31.3 & 38.9 \\
\hline & & 460 & 39.4 & $-^{2}$ & 7.6 & 33.9 & 43.9 \\
\hline \multirow{5}{*}{ Glucose } & \multirow{5}{*}{ P. sajor caju } & 250 & 12.8 & 2.6 & 5.2 & 3.7 & 2.7 \\
\hline & & 275 & 15.2 & 5.4 & 5.6 & 7.6 & 7.0 \\
\hline & & 325 & 15.0 & 6.0 & 12.9 & 14.8 & 16.0 \\
\hline & & 400 & 19.7 & 29.7 & 37.2 & 49.6 & 57.2 \\
\hline & & 460 & 20.8 & 43.4 & 50.2 & 69.0 & 76.3 \\
\hline
\end{tabular}

As shown in Table 3, analysis by GC-MS detected 38 organic compounds in the final effluent prior to contacting with the fungi. Some of these compounds such as guaiacol, syringol, vanillin, vanilic acid, syringic acid, oxalic acid, hidroxypropanoic acid and aliphatic compounds with low molecular weight are probably related to lignin degradation during kraft pulping. Gaiacol, syringol and vanillin are considered the main lignin-derived markers detected in pulps (del Río et al., 2001) and in black liquor from kraft pulp of Eucalyptus wood (Camarero et al., 2007). In the effluent treated with Pleurotus spp., some of these compounds were not detected. Table 3 highlights that after 7 and 14 days of incubation, 17 to 25 organic compounds were not detected, respectively. This fact can be correlated with fungal degradation activity and it could be extrapolated that Pleurotus spp. have performed a complete degradation of lignin with non resulting by-products since the main lignin markers were not detected after 7 days of treatment. Several basidiomycetes fungi were found to be most efficient lignin degraders on Eucalyptus wood (del Río et al., 2001b).

No significant differences were obtained between the two effluent compositions inoculated with $P$. sajor caju or $P$. ostreatus, but longer incubation time reflected higher reduction of organic compounds. Gaiacol, catechol, syringol, vanillin and syringic acid are examples of substances that were not detected after 7 days of effluent treatment. Other substances such as methylbutanedioic, 5-ethyl-3-metoxycatechol, vanilic acid, 1-octadecanol, lignoceric acid and $\beta$-sitostanol were not detected only after 14 days of treatment.

The FTIR results were consistent with those obtained by GC-MS, where a significant disappearance of phenols bands was recorded.

The $P$. sajor caju, a species easy to grow without special needs, has shown a high potential for treatment of effluents from bleached kraft pulp mill processing Eucalyptus globulus, after secondary treatment, especially with addition of glucose $\left(2 \mathrm{~g} \mathrm{I}^{-1}\right)$ as a co-substrate. According 
to Coulibaly et al., (2003), glucose and sucrose are among the co-substrates more indicated for effluent pretreatment at rates of 5 to $10 \mathrm{~g} \mathrm{l}^{-1}$ which are 2.5 to 5 times superior than the rate utilized in this work.

Table 3. Organic compounds detected by GC-MS in final effluent and in treated effluent with $P$. sajor caju or $P$. ostreatus, throughout 14 days of incubation at $25^{\circ} \mathrm{C}$ and $120 \pm 10 \mathrm{rpm}$

\begin{tabular}{|c|c|c|c|c|c|c|c|c|c|}
\hline \multirow{3}{*}{ Organic compound } & \multirow{3}{*}{$\begin{array}{c}\text { Final } \\
\text { Effluent }\end{array}$} & \multicolumn{5}{|c|}{ Effluent/Additives } & \multicolumn{3}{|c|}{ Effluent/Glicose } \\
\hline & & \multirow[b]{2}{*}{ Od } & \multicolumn{2}{|c|}{ P. sajor caju } & \multicolumn{2}{|c|}{ P. ostreatus } & \multirow[b]{2}{*}{$\mathrm{Od}$} & \\
\hline & & & $7 d$ & $14 d$ & $7 d$ & $14 d$ & & $7 d$ & $14 d$ \\
\hline 2-hidroxypropanoic acid & + & + & + & + & + & + & + & + & + \\
\hline hidroxyacetic acid & + & + & - & - & - & - & + & - & - \\
\hline 2-furanecarboxilic acid & + & + & + & + & + & + & + & + & + \\
\hline oxalic acid & + & + & + & + & + & + & + & + & + \\
\hline guaiacol & + & + & - & - & - & - & + & - & - \\
\hline 2-hidroxybutanoic acid & + & + & + & + & + & + & + & + & + \\
\hline 3-hidroxypropanoic acid & + & + & + & + & + & + & + & + & + \\
\hline propanedioic acid & + & + & - & - & - & - & + & - & - \\
\hline catechol & + & + & - & - & - & - & + & - & - \\
\hline butanedioic acid & + & + & + & + & + & + & + & + & + \\
\hline syringol & + & + & - & - & - & - & + & - & - \\
\hline methylbutanedioic acid & + & + & + & - & + & - & + & + & - \\
\hline hidroxybutanedioic acid & + & + & + & + & + & + & + & + & + \\
\hline vanillin & + & + & - & - & - & - & + & - & - \\
\hline 5-ethyl-3-metoxycatechol & + & + & + & - & + & - & + & + & - \\
\hline NID & + & + & + & - & + & - & + & + & - \\
\hline hexanodioic acid & + & + & + & + & + & + & + & + & + \\
\hline dodecanoic acid & + & + & - & - & - & - & + & - & - \\
\hline octanodioic acid & + & + & + & + & + & + & + & + & + \\
\hline 1-tetradecanol & + & + & - & - & - & - & + & - & - \\
\hline vanillic acid & + & + & + & - & + & - & + & + & - \\
\hline azelaic acid & + & + & - & - & - & - & + & - & - \\
\hline miristic acid & + & + & - & - & - & - & + & - & - \\
\hline pentadecanoic acid & + & + & + & + & + & + & + & + & + \\
\hline 1-hexadecanol & + & + & - & - & - & - & + & - & - \\
\hline syringic acid & + & + & - & - & - & - & + & - & - \\
\hline palmitic acid & + & + & + & + & + & + & + & + & + \\
\hline z-9-octadecen-1-ol & + & + & + & - & + & - & + & + & - \\
\hline 1-octadecanol & + & + & + & - & + & - & + & + & - \\
\hline $\begin{array}{l}\text { 1,2,4-benzenetricarboxylic } \\
\text { acid }\end{array}$ & + & + & - & - & - & - & + & - & - \\
\hline stearic acid & + & + & + & + & + & + & + & + & + \\
\hline 1-docosanol & + & + & - & - & - & - & + & - & - \\
\hline behenic acid & + & + & - & - & - & - & + & - & - \\
\hline tricosanoic acid & + & + & + & + & + & + & + & + & + \\
\hline lignoceric acid & + & + & + & - & + & - & + & + & - \\
\hline 1-octacosanol & + & + & - & - & - & - & + & - & - \\
\hline$\beta$-sitosterol & + & + & - & - & - & - & + & - & - \\
\hline$\beta$-sitostanol & + & + & + & - & + & - & + & + & - \\
\hline
\end{tabular}

d days of incubation; + Presence; - Not detected. 


\section{CONCLUSIONS}

Pleurotus spp. is effective and applicable for treatment of a pulp and paper mill effluent. The best results were obtained when the effluent was enriched with glucose, which indicate that this extra carbon source is important for the fungal treatment with $P$. sajor caju. The biological treatment efficiency, in terms of specific organic compounds, was confirmed by advanced analytical techniques such as GC-MS and FTIR.

\section{ACKNOWLEDGMENTS}

This work has been developed under the scope of the FCT (Portugal) funded research project, POCT/CTA/45030/2002: 'Decolourisation of effluents from pulp and paper mills: removal of organic compounds and toxicity (DECORTOX)'.

\section{REFERENCES}

ASTM (1994) Standard Test Methods for Chemical Oxygen Demand of Water, Annual Book of ASTM Standards, Report D 1252-88, American Society for Testing and Material, Philadelphia, USA.

Bajpai P. and Bajpai P.K., (1994) Biological colour removal of pulp and paper mill wastewaters, J. Biotechnol., 33, 211-220.

Belém A., Panteleitchouk A.V., Duarte A.C., Pereira R., Rocha-Santos T.A.P., Freitas A.C., (2006) Biological treatment of Eucalyptus globulus kraft mill effluent by Pleurotys spp., International Congress on Analytical Sciences - ICAS 2006, Moscow, Book of Abstracts, 1, 371

Camarero S., Ibarra D., Martínez A.T., Romero J., Gutiérrez A. and del Río J.C., (2007) Paper pulp delignification using laccase and natural mediators, Enz. Microbiol. Technol., 40, 12621271.

Conesa A., Punt P.J., Hondel C.A.M.J.J., (2002) Fungal peroxidases: molecular aspects and applications, J. Biotechnol., 93, 143-158.

Coulibaly L., Gourene G. and Agathos N.S., (2003) Utilization of fungi for biotratment of raw wastewaters, African J. Biotecnol., 2, 620-630.

del Río J.C., Gutiérrez A., Martínez M.J. and Martínez A.T., (2001) Identification of residual lignin markers in eucalypt kraft pulps by Py-GC/MS, J. Anal. Appl. Pyrol., 58-59, 425-439.

del Río J.C., Gutiérrez A., Martínez M.J. and Martínez A.T., (2001b) Py-GC/MS study of Eucalyptus globulus wood treated with different fungi, J. Anal. Appl. Pyrol., 58-59, 441-452.

Lankinen V.P., Inkeroninen M.M., Pellinen J. and Hatakka A.I., (1990) The cost of lignin modifying enzyme, decreases of AOX and colour removal by white-rot fungi: growth on bleach plant effluent, Water Sci. and Technol., 24,189-198.

Nagarathnamma R. and Bajpai P., (1992) Decolourization and detoxification of extraction-stage effluent from Chlorine bleaching of kraft pulp by Rhizopus oryzae, Applied Env. Microbiol., 65, 1078-1082.

Nilsson I., Moller A., Mattiasson B., Rubindamayugi M.S.T. and Welander U., (2005) Decolourization of synthetic and real textile wastewater by the use of white-rot fungi, Enzyme and Microbial Technol., 38, 94-100.

Palma C., Moreira M.T., Mielgo I., Feijoo G. and Lema J.M., (1999) Use of a fungal bioreactor as a post treatment step for continuous decolourisation of dyes, Wat. Sci. Tecnhol., 40, 131-136.

Pokhrel D. and Viraraghavan T., (2004) Treatment of pulp and paper mill wastewater - a review, Sci. Total Env., 333, 37-58.

Ragunathan R. and Swaminathan K., (2004) Biological treatment of a pulp and paper industry effluent by Pleurotus spp., World J. Microbiol. and Biotechnol., 20, 389-393.

Santos A.Z, Tavares C.R.G. and Gomes-da-Costa S.M., (2002) Treatment of the effluent from a kraft bleach plant with the white-rot fungus Pleurotus ostreatoroseus SING, Brazilian J. Chemical Eng., 19, 371-375. 